ERDÉLYI TUDOMÁNYOS FÜZETEK

\title{
A JOBBÁGYFELSZABADÍTÁS EGYIK LELKES HARCOSA A REFORMKORBAN
}

IRTA

BALOGH ARTÚR

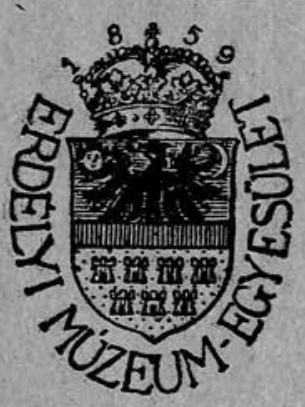

IOLOZS VAR, 1945

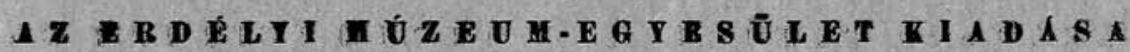




\title{
ERDÉLY I TUDOMÁNYOS FÜZETEK
}

\section{A JOBBÁGYFELSZABADÍTÁS \\ EGYIK LELKES HARCOSA A REFORMKORBAN}

\author{
IRTA \\ BALOGH ARTÚR
}

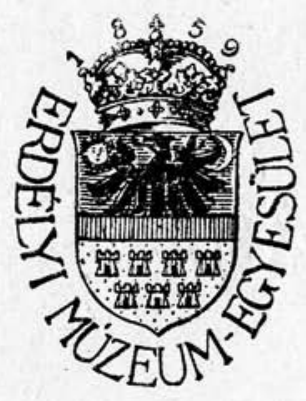

K O L O Z S VÁR, 1945

A Z E R D É L Y I M Ú Z E U M-E G Y E S Ü L E T K I A D I S I 
Különlenyomat

az ERDÉLYI MÚZEUM

1945. évi 3-4. füzetéböl.

(R)

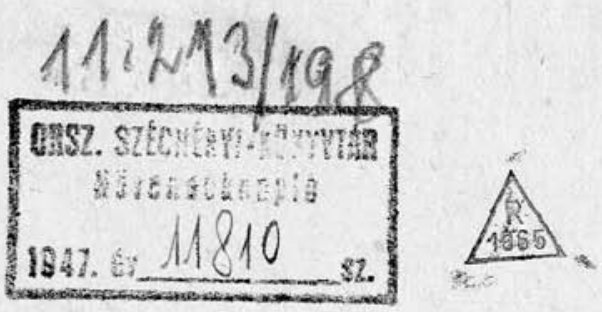

Felelos kiadó: Dr. Szabó T. Attila

Minerva-nyomda Rt. Kolozsvár. No. Clj 12. 7701. F. v.: Kiss Márton igazgató 
A XIX. szāzad reformkornak nevezett első fele olyan kiváló férfiakat állított esatasorba a modern Magyarországért vívott küzdelemben, hogy rájuk mint a hazafiságnak és a nemzet magasabb életszínvonaláért való lelkesedésnek példaképeire méltán mutat reá a történelem. Soraikból kerültek ki a későbbi évtizedek legnagyobb államférfiai. Az utókor emlékezetének azonban nemesak a legnagyobbakat kell számontartani, hanem mindazokat, akik elismerést érdemlő módon kivették részüket a modern magyar állam megteremtésének munkájában.

Ezek között foglal helyet és pedig nem az utolsó sorban az egykor híres, ritka népszerüségű barsmegyei követ, BaLoGH János, aki rettenhetetlen bátorsággal küzdött a bécsi politika alkotmányellenes törekvéseivel szemben, de e mellett egyik leglelkesebb harcosa volt a jobbágyok felszabadításának, három hütlenségi pere közül az egyiket éppen a jogtalan nép érdekében mondott országgyülési beszéde miatt indították ellene és az emberiességgel és a század lelkével rútul ellenkezö botbüntetésnek azonnali feltétlen eltörlését követelte akkor, amikor azt sokan, köztük még Széchenyi is, időelőttinek tartották. Az ellenzék egyik vezére volt Deák Ferenc és társai mellett az 1832-6-i országgyülésen s ebben az időben Wesselényin kívül nem volt népszerübb embere az országnak. A nép érdekében mondott tüzes beszédeinek köszönhette jó részben, hogy nevét az önkényuralom 1849-ben bitófára akasztaitta s kimenekülve, tíz évig volt kénytelen enni a bújdosók keserü kenyerét.

Galanthai Balogh János 1796. február 22-én született Nagyendréden, Bars megyében. A családnak több jeles tagja volt. fgy BALOGH Mıkцós (1625-1689) váci püspök, akinek a török hódoltság megszünése után nagy része volt a város újjáépítésében, BaLoGH IstváN II. Ferdinándnak több ízben törökországi követe volt, egy másik Balogh István Rákóczinak brigadérosa. Balogh Jánosnak hasonnevü atyja nyole országgyülésen (1792-1825) volt követ. A régi források „a híres követ" megjelöléssel emlegetik, akinek krédója volt mindíg ellenkezőjét akarni annak, amit az udvar és a kormány kívánnak, mert az nem lehet helyes, nagy ellenzékiségéről Deák és Széchenyi is megemlékeznek.

$\mathrm{Az}$ 1830. év, amikor BALOGH János először jelent meg az országgyülésen, a nemzeti ébredésnek, a modern állam megvalósítását célzó törekvéseknek jeleit még alig mutatja. Széchenyi fellépése óta (Hitel 1828) megkezdődött ugyan a korszellemnek a haladás irányában való 
átalakulása, de ez igen lassan ment. Az ország alig volt előbb, mint száz év elött. A magyar közállapotok és a nyugateurópaiak közöitti nagy különbség a ,legnagyobb magyar" fellépése óta volt látható. Hogy ennek és a haladás, amint mondotta: ,a szelíd és konvulzió nélküli reformáció" szuikségességének tudatára ébresztette az alvó nemzetet, ebben van az ő nagy jelentősége és érdeme.

Reformokat komolyan sem a kormány nem akart, sem a közhangulat nem sürgette még őket, bár a fiatalabb nemzedék a francia és német liberálizmus eszméit móhón szívta magába. A kor legtöbbjének gondolkozásában a híres ,primae nonus" ${ }^{1}$ örök érvényű alaptörvényként élt, és minden változtatást az ősi alkotmány veszélyeztetésének tekintettek. Reformokra azonban elsősorban az uralkodó és őt befolyásoló környezete nem gondolt, hiszen I. Ferenc (1792-1835) kormányzati eszménye a rend és nyugalom, a patriarchális abszolutizmus, amely a francia forradalom és a Martinovics-féle összeesküvés hatása alatt mindenben a forradalom rémét látta, és semmi változtatásról nem akart hallani. Ennek a kormányzati szellemnek a béesi kormányban METTERNich herceg - kancellár 1821-től 1848-ig - volt legföbb pártolója. De a fennállóhoz való merev ragaszkodásban nagy segítőtársat nyert ez az irány a magyar fönemességben, amely a demokratikus haladástól kiváltságait féltette.

Balogh János már 27 éves korában olyan heves ellenzéki tevékenységet fejtett ki atyịa mellett Barsban és Nyitrában, hogy atyjával együtt a királyi fenyítő szó hallására (ad audiendum verbum regium) Ferenc király maga elé idéztette s megdorgálta. Ez azonban csak megszilárdította ellenzékiségében és olyan népszerüvé tette, hogy már az 1830-i országgyúlésre Bars megye követéül választotta. Már ezen az országgyülésen kitünt az alkotmány védelmében tanúsított bátor fellépésével. Ferdinánd megkoronázása és a hitlevél, az ujıncok megajánlása, a magyar ezredekben magyar tisztek alkalmazása s a magyar vezényleti nyelv, a feliratok és törvények magyar szövege és a vallásszabadság voltak azok a föbb kérdések, amelyekhez hozzászólott. BALOGH Jánosnak azonban a nép felszabadítása érdekében kifejtett működése főleg az 1832-6-i országgyülésre esik. A kormány elött már ekkor olyan ellenszenves volt személye bátor fellépése miatt, hogy mindent megkísérelt megbuktatására. Keglevich JÁNos barsi föispán az elszegényedett köznemeseket a legnagyobb vesztegetésekkel, etetés-itatással igyekezett tőle eltántorítani; ez a fáradozás azonban teljes kudarcot vallott.

A XIX. század harmadik évtizdétől számithatjuk azt az időszakot, amidőn új szellem kezdi áthatni a magyar életet. A nemzeti gondolat minden téren érvényesülni törekszik. Kazinczy vezetésével újra éled századeleji dermedtségéből az irodalom. Megalakult a Tudós Társaság. Magyar színészek játszanak nemesak Kolozsváron az első állandó színházban, hanem magyar színtársulatok járják a többi váro-

1 Vö. Werbőczy Hármaskönyve I. részének 9. címe, amely a nemesi kiváltságokat tárgyalja. 
sokat is. Bihariban megtalálja a magyar zene külföldön is megbámult első mesterét, a magyar zene nemesak müvészet, hanem a nemzeti müveltség eszköze.

A politikai életet is új szellem hatja át. Az 1832-36-i országgyüléstől kezdődik ugyanis a magyar politikai fejlődésnek az a megszakítás nélküli, határozott iránya, amely a rendi állam megszüntetését, a nemesi kiváltságok eltörlését s ezzel a modern jogegyenlőségi állam megteremtését, a szabadelvi̋ haladást tüzte céljául. Ez az országgyưlés már egészen nemzeti szellemü. De voltaképpen nem új eszméket hozott felszínre, mert azokat az eszméket, amelyekért küzdelmei folytak, jórészt megtaláljuk az 1790-i országgyülés tárgyalásaiban, követi utasításaiban és az egykorú politikai irodalomban. A modern állam megteremtése azonban lassan halad előre. Az országgyülésnek csak a jobbágyok helyzetén sikerült könnyiteni, de lényeges változás, hogy a közjogi kérdések helyett a társadalompolitikaiak lépnek elötérbe bevezetéseül annak a reformkornak, amelynek szelleme a 48-as törvényhozás eredményeiben nyert teljes érvényesülést, miután ezt a szabadságeszméknek a nyugateurópai országokban ellenállhatatlan erejü elôretörése is elösegítette. Nem az elért eredményt tekintve, amely nem áll arányban a kifejtett erőfeszítéssel, van jelentősége az 1832-36-i országgyúlésnek, hanem abban, hogy a nemzet a négy évtized előtt megkezdett útra visszatért.

Az országgyülés alsótáblai ellenzékét áthaitotta már a szabadelvü eszmeáramlat, amelynek nem angol, hanem francia mintája után indult s amely a XVIII. század második felének nagy francia állambölcselői után az ember és polgár jogainak az északamerikai államok alkotmányaiból átvett 1789-i francia kinyilatkoztatásában, majd az 1791. évi francia alkotmányban állapitotta meg a szabadelvüségnek gyakorlati politikai tanait. Nálunk is ismertek lettek a forradalom liberális irányú történetíróinak művei épp úgy, mint azok a lelkes szónoklatok, amelyek a francia parlamentben a szabadelvüség dicsőitésére elhangzottak, ellenhatásként arra a szabadságellenes kormányzatra, amely náluk a XIX. század második évtizedében lábrakapott. Közvetítője volt a szabadelvü eszméknek Németország is, ahol azok már szintén meghódították a közvéleményt.

A közhangulat mindenesetre gyökeresen megváltozott. Mindinkább belátták az ország elmaradottságát, az alsó osztály helyzetének tarthatatlanságát. Elmúlt az a kor, amely mindent úgy láitott leg.jobbnak, amint van és különb életet a magyarországinál nem is tudott elképzelni. ${ }^{2}$

$\mathrm{Az}$ 1832-36. évekre esik BaLogh politikai tevékenységéniek förésze. Az alsó tábla reformpárti ellenzékének egyik vezére volt. Ezen

2 Losonezy István 1772. évi munkájában, a Hármas Kis Tükörben találjuk a híressé vált mondást: ,Extra Hungariam non est vita, si est vita, nop est ita" (Magyarországon kívül ninesen élet, ha van, ilyen nem lehet). Ezt Széchenyi hiábavaló és kacagást vagy szánakozást okozó beszédnek minősítette (Hitel). 
az országgyülésen fejtette ki a legélénkebb tevékenységet a szabadelvü reformok, nẹvezetesen a jobbágyok helyzetének gyökeres megváltoztatása érdekében; e mellett még föleg a vallásszabadságért küzdött. Erre az időre esik a lengyelek szabadságának visszaállításáért való síkraszállása. Ebben a kérdésben kezdeményezőleg lépett fel az alsó táblán. Ugyancsak ekkor történt hütlenségi perbe fogása Wesselényi nagykárolyi beszédének az országgyülésen való helyeslése miatt, ami Wesselényi hasonló ügyével együtt mint a szólásszabadságon esett sérelem hónapokon át foglalkoztatita az országgyülést és amely két ügyben a főrendeknek a felírást ellenző magatartása még mélyebbé tette a két tábla közti szakadékot. ${ }^{3}$ Végül az országgyülés befejezése után történt a reakciós kormány müveként az országgyülési ifjaknak, Lovassy LÁszLónak és három társának elfogatása, akiknek kiszabadítása érdekében megyéjében, Barsban szintén nagy tevékenységet fejtett ki. Mindezekben az ügyekben olyan buzgalmat tanúsítatt, hogy megyéjének elismerését a legnagyobb mértékben kiérdemelte és megyéje még két ízben küldötte fel az országgyülésbe, hü maradván hozzá tíz évi, sok szenvedéssel járó emigrációjából való visszatérése után is.

Az 1832 -36-i országgyülés folyamán, amely negyven hónapig tartott, került sor 1833-ban az úrbéri munkálatra. Ennek tárgyalását a kormány kívánta; ez volt az országgyúlésnek legfontosabb tárgya, amelyet ha nem is sikerült teljes mértékben megoldani, mégis jelentékeny eredmények érettek el a jobbágyok helyzetének javítására.

Azok közt, akik ebben a fontos kérdésben buzgóllkodtak, ott volt Deák Ferenc, Kölcsey ferenc, Felsőbükki Nagy Pál, Bezerédy István, PaLóczy László mellett BaLOGH is. Müködésének jelentékeny része ennek a kérdésnek tárgyalására esik. Itt mutatta ki leginkább a jogokkal nem, esak kötelességekkel bíró nép iránti rokonszenvét és a haladás iránti lelkesedését.

Hogy a haladott szellemüek által már szükségesnek ítélt reformokért lelkesedő férfiak lankadatlan küzdelmét kellően értékelhessük, vázolnunk kell azokat az állapotokat, amelyeknek megváltoztatását ők kívánták. A korszakalkotónak igérkező reformjavaslatok idején a magyar társadalom szorosan elkülönült osztályokra tagozódott. A tömeges honfiúsítások révén származásilag is nem magyar, esekély kivétellel a nemzettől elindegenedett, külföldön, föleg az udvar árnyékában Bécsben élő főnemesség egyáltalában nem érezte a reformok szükségét. Az 500 förend most is szembehelyezkedett a 700.000 közmemes képviseletével. Haladottabb gondolkozásúak a mintegy másfél millió városi polgárságban alig voltak, követeik a kormány szekerének voltak taszítói. A társadalom legnagyobb számú osztálya a jobbágyság, a század harmadik évtizedében mintegy 8 millió a 11 milliónyi összlakosságból. Helyzetük Mária Terézia 1768-i úrbéri szabályzatának kibocsátásáig mindenesetre igen súlyos. 1514-ben megszünt szabad

3 Vö. tőlem Hűtlenségi per országgyülési beszéd miatt: EM. 1944:279 kk. és kny. ETF. 185. sz. 
költözködési joguk, így Werböczy szerint földesuraiknak teljes éø örökös szolgasággal alávetettek, röghöz kötöttek lettek. Helyzetüket a rendek 1546-ban maguk is égbekiáltónak mondják. A XVIII. században a nagyobb földbirtokosok áttértek az intenzívebb gazdálkodásra, ami a jobbágy erejének mind nagyobb igénybevételét vonta maga után. Sorsukon javítani akarván, Mária Terézia 1768-i úrbéri szabályzatában (urbarium) egységesen állapította meg eddig a földesurak tetszésétől függött kötelezettségeiket az általuk használt földesúri telkekért. Ezek különböző szolgáltatásokból és szolgálatokból (ingyen munka, robot) állottak. De a jobbágytársadalom is különbségeket mutatott, amennyiben a nyolcad teleknél kevesebbet használók zsellérek és ezen kívül föld és ház nélküli zsellérek is voltak. Polgári és politikai jogaik nem voltak, bírájuk nemesak a jobbágyok közötti, hanem a földesúr és a jobbágy közötti perekben is a földesúr. Adó, a diétai követek napidíjának fedezése, előfogatállítás, katonáskodás csak a jobbágy terhe volt. Uraikban megvolt a hajlandóság, hogy a törvényes mértéken tú] terheljék őket, de mindent összevéve nem lehet mondani, hogy roszszabb sorsuk volt, mint a legtöbb más államban. A jobbágy urával szemben nem állott védtelenül, az úriszék ítéletével szemben a vármegyéhez és a helytartótanácshoz fellebbezhetett, s úgy ez, mint a kancellária jóakaratot mutatott a jobbágyokkal szemben. A reformjavaslatok idején már kötelezettségeinek teljesítése után szabadon költözhetett, fia szabadon tanulhatott és tanult pályára léphetett. A XIX. század első évtizedeiben is a gimnáziumok tanulóinak tekintélyes része jobbágyfiú. A birtoktalan, illetőleg törpebirtokos ú. n. boeskoros nemesek életszínvonala alig különbözött a jobbágyétól,

Sajátságos a reformokat ellenzők gondolkozása. A jobbágyság nehéz helyzetét elismerik, de változtatásról nem akarnak hallani, me reven ragaszkodnak ellenérveikhez, amelyeknek igazságáról meg vannak győződve. A jobbágyok birtokképességének megadásától egyenesen az alkotmányt féltik, az úriszéket helyes intézménynek tartják, mert az gyorsan, olesón és alaposan dolgozik, a földesurat patriarchális jóindulat vezeti (több ellenzéki kimutatta ennek az érvnek tévességét), a jobbágy személyének biztosításával szemben azt hozzák fel, hogy ez a jobbágyot teljesen hasznavehetetlenné teszi. Pedig, amint Nagy Pál erre felhívta a figyelmet, már a jobbágy is kezdett gondolkozni azon, hogy mindennek úgy kell-e lenni és örökké fennmaradni.

Reformot esak az alsó tábla szabadelvű ellenzéke kivánt. Az úrbéri javaslatáért folytatott küzdelemben a köznemesség saját osztályérdeke ellen az alsó néposztály érdekéért harcolt, míg a kormány a kiváltság fenntartása, a nép felszabadítása ellen foglalt állást, bár a javaslat tárgyalását ö kívánta. Hajlandó volt a jobbágyok anyagi helyzetén javítani, de erre sem szociálpolitikai szempont indította, hanem esak az, hogy őket az adózásnál jobban igénybevehesse. Mint úgyszólván minden törekvésében, most is hü támogatókra talált a főrendekben, akik csak féltve örzött kiváltságaikat akarták megtartani; ezzel azonban a nemzeti szellemtől elidegenültségük révén megérdemelten szerzett népszerütlenségüket még inkább növelték. 
Június közepére a kerületi ülésekben befejezték az országos bizottmány munkálatának felülvizsgálatát, és elkészült az új úrbéri szabályzat, amely már a rendek tábláján nehezen ment keresztül, mert még mindíg sokan ragaszkodtak a nemesi kiváltságokhoz. A kerületi ülésekben elfogadott javaslat főbb intézkedései a következők. Kimondják a jobbágyok szabad költözködését, mi által a jobbágy- vagy zsellértelek haszonvételéből származó minden jobbágyi kapesolat megszünik. Megengedtetik, hogy a jobbágy a telek haszonvételi jogát a földesúr beleegyezésével, a földesúr és a községek kivételével, bárkinek eladhassa. Az egy községben megszerezhető telek maximuma meg van állapítva. A jobbágyi szolgáltatások korlátoztatnak, illetőleg azok megszünnek. Tartozásaikat a földesúrral való szabad egyeség által örökre megválthatják. Lényeges kedvezmények adatnak az igazságszolgáltatás, továbbá a jobbágyok személyének és vagyonának biztosítása tekintetében. Nevezetesen a jobbágyot bírói ítélet nélkül sem személyében, sem vagyonában nem lehet háborgatni, a jobbágyok a jövőben saját nevükben folytathatnak pert nemes személyek ellen, végül a földesúr és a jobbágyok közti polgári perek a megyei törvényszékekhez tartoznak.

$\mathrm{Az}$ úrbér rendezésének legfontosabb kérdése az úrbéri tartozások állandó megváltása (örökváltság) volt. $\mathrm{E}$ körül folyt a szabadelvủek legszívósabb, legelkeseredettebb küzdelme, miután ezt sem a förendek, sem a kormány. nem akarta. Balogh ebben a kérdésben ismételten felszólalt. Elsőizzben az 1833. szeptember 4-i ülésben mondott hosszabb beszédet, lelkesen síkra szállva az örökváltság mellett. Ebben az ülésben a személynök ${ }^{4}$ ellene szólott annak, hogy a jobbágyságnak a tulajdon.jog nemesi birtokra megadassék, mert ezzel a jobbágy és a földesúr közti viszonyok egyszerre meg lennének szüntetve. Balogh hosszabb beszéddel szállt szembe a személynökkel:

„Hallotta mondani- így kezdte-, hogy sokkal könnyebb nyolc millió embernek ügyét pártolni, mint négyszázezernek. De ő éppen az ellenkezőt hiszi, mert országunkban négyszázezer hoz törvényt a nyole milliónak, és így a morális erő a négyszázezernél van. Hallotta az egyik követtől, hogy fél a francia revolució minden rendet megrázó elveitől. De úgy gondolja, hogy a jobbágyságnak adandó tulajjonjog még messze van a francia revolució elveitől és messze vagyunk még azon időtől is, amikor nálunk is a francia nemzet chartája fog virágozni. Utasításának nagy betükkel kiírott vezéresillaga a jobbágyságnak engedendő tulajdonjog, amelyet ez bizonyos, a földesúr úrbéri jövedelméhez képest. meghatározandó mérsékelt kárpótlás mellett megszerezhessen. Amíg a nem nemesnek ingatlani tulajdon joga nem lesz, őt polgárnak nem lehet tartani, aki pedig nem polgár, annak hazája ninesen s akinek hazája ninesen, annak szívében nem létezik

${ }^{4} \mathrm{Az}$ alsó tábla elnöke, aki a kormảnynak egyetlen képviselöje. İgy szerepe is más, mint a mai elnöké. Saját nézetei elóadásával vezeti be a tárgyalásokat, természetesen a kormány szándékait tartva szem előtt, cáfolja az ellenkező vélemény'eket és igyekszik a kormány kedve szerint való határozatokat elfogadtatni. 
a haza iránt való szeretet, ez a szent érzés, amely minden polgári erénynek kimeríthetetlen forrása. Ha tehát azt akarjuk, hogy a paraszt hazánkért vérét öntse, azt velünk kezeit fogva védelmezze; ha azt akarjuk, hogy az uralkodóknak néha a korlátlanság után vágyó hatalma némiképen zaboláztassék, öntsünk bele a tulajdonjog engedménye által hazaszeretetet és ez által a most keblében irántunk rejtőző ellenséges érzést változtassuk át irántunk érzendő bizodalommá. Altallátták ezt Európának minden müvelt nemzetei és a durva század durva jobbágy nevét az édesen hangzó polgár névvel eserélték fel. Ott a legnagyobb úrtól kezdve egész a nyomorult napszámosig mindenki büszke a polgári névre; ott virágzik a polgári egyformaság, mely a mostani felvilágosodott századnak bálványa.

Ha a földesúr a mostani úrbéri jövedelmeinek tőkéjét megkapja, veszteni semmit sem fog. Mi tehát a földesúr úrbéri jövedelme? a kilenced, a robot és némely apróbb tartozások. Forditsuk mindezeket pénzre tíz vagy húsz esztendőknek általános ára szerint; ha ezen calculusból kitünő summának tőkéjét megkapja a földesúr, úgy ismét áll az, hogy semmit sem vesztett. Igaz ugyan, hogy az egész úrbéri telek többet ér, mint amennyit ezen jövedelemnek tökéje teszen, mert ebből él, azon felül a jobbágy ebből fizeti az adót, ebből tartja a katonát, ebból szolgál az egész széles világnak. De ez a földesúr zsebébe sohasem jött, ő tehát többet nem kívánhat, esak annak, ami zsebébe jött, tőkéjét. Az tehát, ami a földesúr jövedelmének tőkéjét teszi, a földesúré, ami pedig a jobbágy jövedelmének tőkéjét teszi, a jobbágyé és íme itt van a két jövedelemnek demarcationalis lineája.

Tudjuk azonban azt, hogy hazánkban a jobbágyság általában annyi pénzzel és móddal nem bír, hogy mindenki a földesúr tőkéjének jövedelmét lefizethesse; a gazdag le fog.ja tenni a tőkét és magát emancipálja, a szegény pedig örökké jobbágy marad. De ezen ismét segíteni lehet, úgy tudniillik, hogy a földesúr kapja meg jövedelmének tőkéjét földben és rétben, a jobbágy is kapja meg jövedelmének tőkéjét földben és rétben, mindenesetre pedig neki optió adassék, vaj.jon pénzzel akarja-e magát kiváltani vagy pedig in natura akarja a maga részét a fentebbi calculus szerint kivenni."

$\mathrm{Az}$ előlülőnek azon észrevételére, hogy ha a jobbágyságnak megadódna a sajátság, ${ }^{4 a}$ akkor megszünnének egyszerre a földesúr és jobbágy közt fenálló viszonyok, röviden azt feleli, hogy ezt igenis elhiszi, de ez az ő forró kívánsága egyszersmind, hogy ami durva századokra emlékeztet, megszünvén, már valahára a jobbágy a magasabb emberi állásra felemelkedjék."

$\mathrm{Az}$ előlülő, (mert neki mindíg kellett a követek beszédét cáfolni, ha nem a kormány szája íze szerint beszéltek) azt válaszolta Balogh fenti beszédére, hogy a nyolcmillió nemtelen lakosok nem köszönnék meg, ha őket azon hazától, amelyet annyi századokon át védtek, megfosztanák, valamint a barsi követnek nem köszönnék meg azon állítását sem, hogy nékiek hazájok ninesen.5

4a Azaz a tulajdonjog.

s Jegyzőkönyv IV, 107-9. 
$\mathrm{Az}$ 1833. október 12-i ülésben Balogh ismét felemelte szavát az örökváltság érdekében. - „Azt mondani, hogy a jobbágy magát ki ne válthassa, nem egyéb, mint azt mondani: Te jobbágy szolgának születtél, neked örökkön örökké szolgának kell maradnod. A főrendek az ősiségtől félnek, hogy ezen intézkedés által elveszne. Erre csak azt feleli, hogy ettől éppen nem fél, mert azt kívánja, az egészen eltörültessék. Arra, hogy javaslata alkotmányunk megrontására szolgál, azt feleli, hogy a mostani alkotmány alapjait ugyan felforgatni nem akarja, de minden alkotmány legfőbb tökéletességének tekinti annak változhatóságát $\mathrm{s}$ igen nagy tökéletlenségnek tartaná, ha alkotmányunkat változtatni nem lehetne."6

$\mathrm{Az}$ örökváltság ügye már az alsó táblán is kedvezőtlenül alakult, amennyiben az ezt pártoló megyék száma a november 10-i ülésben 25-re olvadt le. A javaslaitot a november 19-én a förendekkel együtt tartott vegyes ülésből terjesztették fel. A királyi válasz csak kilenc hónap múlva érkezett le és nagy részben elutasító volt. Eddig a kormány mutatta magát a köznép pártolójának, kívánta az úrbéri ügyeknek első sorban tárgyalását. A javaslat legfontosabb pontjainak viszszautasításával azonban most megmutatta, hogy szabadelvü, gyökeres reformra nem hajlandó. Az örökváltság visszutasításának fő oka az volt, hogy a király elött minden oldalról aggodalmakat fejeztek ki a miatt, hogy ez által egy új, még nem ismert népes osztály állana elö és ezen gyors változásból könnyen zavarok támadhatnának. ${ }^{7}$

A szabadelvüek azonban nem lankadtak. Tovább folyt a küzdelem, hogy mentsék, ami menthető. „És Deáknak - írja Horvátr MrHály - Kölcseynek, Bezerédynek, Beőthynek, Baloghnak és több másoknak kívánt alkalom nyujtatott, ékesszólásuk diadalmas erejével kellő világba állítani a nép milliói polgári jogosításának szent ügyét s meggyőzni mindenkit annak múlhatatlan szükségéről az ország általános jóllétének emelésére“. „Kölesey, Deák, Beőthy, Klauzál, Balogh, Palóczy s az ellenzék más tagjai egymással nemesen vetélkedve küzdének a jobbágyok felszabadításának első szükséges feltételéért, az örökváltságért".8

A királyi válasz az 1834. november 10-i ülésben került tárgyalásra. Ebben és a december 10-i ülésben folytak a leghevesebb harcok az örökváltságért. November 10 -én az ülés délelött 10 órától délután fél 7-ig tartott. Deák, Kölcsey, Nagy Pál, Klauzál, Bezerédy mellett Balogh is utolsó erőfeszítéssel küzdött az ügy sikeréért. Az úrbéri V. törvénycikk 2. §-a szólott a jobbágytelkekről, közös szerződésekről és azoknak örökös felváltásáról. Balogh ekkor a következő beszédet mondotta:

„Az 5-ik articulust, amely a jobbágyság örökös kiválthatását tárgyazza, el nem fogadni annyit teszen, mint egy lélek és életerö nélküli testet alkotni. Annyit teszen, mint a jobbágyságot a tulajdon

6 I. h. V, 210.

7 Wirkner, Élményeim 71.

- Horváth Mihály, Huszonöt év Magyarország történelméből. ${ }^{2}$ I, 376-7. 
birhatás édes reményétől, minden polgári társaság leghatalmasabb osztöne és rúgójátôl örökre megfosztani. Annyit teszen, mint a magyar jobbágyságot örökös szolgaságra kárhoztatni éspedig azon jobbágyságot, mely századoktól fogva egyedül viseli hazánknak közterheit, mely sokszor akarata ellen is vérével védelmezi hazánkat és amelynek kézi munkája nélkül a nemesi rend minden hatalma és birtokainak roppant kiterjedése mellett is csak igen soványan vagy épen nem élhetne...

Igaz, hogy az úrbéri javaslatban némely engedmények vannak, aminő a haszonvételnek szabad vevése, eladása, az ugar kilenced megszüntetése, a kisebb praestatiók elengedése, stib., de mindezen engedményeket szívesen vissza lehet adni az 5 . szakaszért, mert az embernek legfőbb kincse a szabadság, amit legalább részben ezen szakasz által érhet el. Talán azt vélik némelyek, hogy a jobbágyság arra, hogy magát örökösen kiválthassa, megérve nincsen. De vajjon miféle érettség kell arra, hogy valaki örökös szolga ne legyen? Meg kell vallani öszintén, hogy a nemesi rend nagyobb része részint szegénysége, részint nevelésének hiányai miatt értelmiségi tekintetében nagyon hátra maradt. Ha tehát a nemesi rend nagyobb része, akik az intelligenciának esak azon fokán állanak, amelyen az adózó nép, már századoktól érett arra, hogy minden nemesi szabadsággal éljen, miért ne legyen az adózó nép a 19. században megérve arra, hogy magát örökösen kiválthassa? Vagy talán attól félnek némelyek, hogy ha a jobbágyság magát kiválthatja, nem fog itt megállni, hanem mindig feljebb és fellebb akar majd lépni? De ha őseink fellebb és fellebb nem léptek volna, nem állanának-e sokan azok közül, akik ma nemesi szabadsággal dicsekedhetnek, a jobbágyság soraiban? Tekintsünk szét Európának alkotmányos országain, találunk-e csak egy nemzetre is, ahol a jobbágyság magát vagy már ki nem váltotta volna, vagy efféle kiválthatását a törvény tiltaná? Ha a lengyelek Kosciusco példáját követték volna, aki jobbágyait felszabadította, most talán a lengyel nemzet hősei nem lennének kénytelenek sem Szibériában fázni, sem idegen országok tüzhelyeinél melegedni.

A kormány a materiális engedményeket két kézzel elfogadja, a morális engedményeket pedig vagy éppen megtagadja, vagy azokat bizonytalan messze időkre halasztja. A kormánynak két célja van. Az egyik az adózási alap emelése, a másik az eddig gyakorolt önkénynek fenntartása. Az usust meg akarja tartani azért, hogy ebben a helytartótanáes ítélhessen, s ez által a kormánynak eddig gyakorolt önkénye fennmaradjon, ezekben a kérdésekben a nagy úr nyerjen, a szegényebb nemes ember veszítsen. A materiális engedményeket nagy bőkezúséggel szórja a kormány, hogy a jobbágyság jobban és többet fizethessen. Bízik abban, hogy ha a jobbágy jobb sorsra jut, az országgyűlés hajlandóbb lesz nagyobb adó megajánlására. Igaz, hogy az adó felemelése nem a kormánytól, hanem az országgyüléstől függ. De a kormány igyekezni fog a vármegyék rendeit befolyásolni, a kormánynak ezer és ezer módja van különféle titkos és nyilvános utakon a jobbágyság jobb sorsából hasznot húzni, 
Az 5. szakasz által senkinek tulajdona meg nem sértetik. A földesúri tulajdon még akkor sem lenne megsértve, ha a szakasznak kötelező ereje lenne, vagyis azt mondaná, hogy a törvény által megállapított szabályok szerint minden földesúr köteles jobbágyart felszabadítani, mert ezt az állam érdeke, az, hogy mindenki szabad lehessen, megkívánja. De a szakasz szerint minden földesúrnak tetszésétől fog függeni jobbágyaival megegyezni vagy nem.

A karok és rendek kétféle engedmények által akarják a jobbágyságot boldogítani: materiálisokkal és morálisokkal. Az elsőkkel azért, hogy röviden mondva a jobbágynak több kenyere legyen, morálisokkal azért, hogy a jobbágyságot alacsony sorsából kiemelve a szónak valódi értelmében emberré tegyék. A jobbágyság kiválthatását az öszszes úrbéri rendelkezések közt a legfontosabbnak tartja. Ezért állhatatosan megmarad az 5. szakasz mellett és szívéböl örülni fog, ha azt, amit Isten és a természet ingyen adott az embereknek, hazánkban legalább pénzen megvásárolni lehetne."

Az 1834. december 10 -i ülésben még egyszer felszólalt az V. úrbéri törvény mellett. Azok sorában akar állani, akik ha az V. úrbéri törvénycikkely elesne, szomorú, de büszke érzéssel azt mondhatják: mindent elvesztettünk, csak becsületünket nem. Megállapítja, hogy a törvénycikk barátai nem vívtak oly lelkesedéssel annak megtartásáért, mint ellenségei annak eleséséért. A kerületi ülésekben harminchárom vármegye állott az V. cikkely mellett és már a november 10-i országos ülésben számuk huszonötre olvadt le. Felszólítja a haza minden fiát, hogy ezen törvénycikkelyt, amely a jobbágyság örökös kiválthatását tárgyazza és amelytől nemesak a több millióból álló adózó népnek, hanem magának a nemességnek is jövendő felvirágzása függ, soha el ne hagyják. ${ }^{10}$

$\mathrm{Az}$ 1835. április 9-i ülésben a turócmegyei első követ tiltakozott Balogh beszédének ama kitétele ellen, amely szerint ,mindent elvesztettünk, csak becsületünket nem", mivel ez homályt vet azokra a megyékre, amelyek nem pártolták a megváltást.

Minden buzgolkodás az örökváltság megmentése érdekében hiábavalónak bizonyult azonban, mert a kormány elővette bevált módszerét, a főispánok útján nagy nyomást gyakorolt a megyékre, hogy utasításaikat változtassák meg a javaslat elbuktatására. Ennek azután meg is lett a tőle kívánt eredménye. A három nagyfontosságú javaslat: az örökváltság, az úriszékek korlátozása és a jobbágyok személyének és vagyonának biztosítása a december folyamán tartott ülésekben heves viták után megbukott, illetőleg a királyi válasz értelmében módosították őket. A királyi válasz pedig az úrbért egyáltalában nem fogadta el, és fenntartotta némi módosítással az úriszéket. Az 1834. december 30-án tartott ülésben tárgyalták utoljára a jobbágyok személyét és vagyonát biztosító javaslatot. „Deák, Nagy Pál, Klauzál, Palóczy, Beőthy, Balogh s több más szabadelvü követek még egy

9 Jegyzökönyv IX, 231-5.

10 I. h. 475 . 
ostromot kíséreltek meg a kormánypárt ellen s lelkesedésben és ékesszólásban önmagokat is meghaladni látszának, hogy a nagyfontosságú törvénycikket megmentsék" - írja Horváth Minály. ${ }^{11}$ Deák a nála megszokott erős logikával cáfolta a kormánypárt által felhozottakat. NAGy PÁL igen éles szavakkal mutatott rá arra, hogy nálunk minő bátorságban van a jobbágy személye az eddigi törvények mellett. „Balogh János - olvassuk ismét HoRvátmnál - a már kétségtelen kimenetelű végszavazat előtt még egyszer felszólalt; nem többé a már lehetetlen diadalért küzdendő, hanem a közügyek s a törvényhozás helyzetét ábrázolandó. Szónoklata mintegy halotti beszéd gyanánt tűnik elő azon fényes remények sírja felett, melyekkel magát a szabadelvü reformpárt az országgyúlés kezdetén a hon újjászületése tekintetében kecsegtette".12

Beszéde, amely e fontos reformkérdés iránti lelkesedését leginkább mutatja, a következő:

„Elveszett immár az általunk javasolt V-ik úrbéri törvénycikk 2-ik szakasza (az örökváltság), amely ha megáll, egy új dicső korszakot vala teremtendő a hazában; elvesztével pedig örökös szolga most már a magyar jobbágy s a XIX-dik században is csak ott áll, nová őt elődeink buzogányai taszíták. Elveszett a VII-ik cikkely is (az úriszékek korlátozása) s annak elvesztésével hazánkban a legszámosabb felekezetnek bírósága a részrehajló igazságnak képrajza marad. El fog veszni, amint látni lehet, nemsokára a VIII-ik törvénycikk is, mely a jobbágy személyét biztosítaná s elvesztével a kegyetlen földesúr kínzó pálcája gúnyolva neveti ki az azt széttörni akarókat..." „A kormány maga is a királyi előadásokban sok szép szavakba burkolt igéretek kecsegtetésével a megoldást látszott kívánni. A nemzettől annál többet várhatánk, minthogy hazánknak egy jeles fia ${ }^{13}$ lángésszel és hazafiúi lelkesedéssel teljes iratai által a felvilágosodás fáklyáját jóval ez országgyülés előtt meggyujtotta."

. Nagy volt a remény, feszült a várakozás. És íme mi történik? $\mathrm{E}$ folyó évi augusztus 28-án minden hazafi dobogó szívvel sietett az ország házába, hol a királyi válasz rettentő villám és mennydörgés közt felolvastatott, mintha foglalatján magok az egek is bosszankodnának. És a nemzet s főkép az adózó nép legszebb reményei egyszerre meghiúsultak."

„... fgy vész el hazánkban-minden nemzeti ügy, s így fog elveszni mindaddig, míg az országgyülés úgy marad alkotva, ahogy most áll; míg tudniillik a kormánynak és a förendeknek korlátlan vetója lesz, míg a vármegyék önállóbbak, a királyi városok függetlenebbek nem lesznek, míg az egyházi rend a világi törvényhozásban részt veszen, míg minden hivatalok kiosztása a kormány kezében marad és ezek által a nemzet meggátoltatik serdülő erejét lehetőleg kifejteni. Mikorra lehet pedig remélni, hogy e kifejlés létesüljön oly országban,

11 Huszonöt év I, 398.

12 I. h. 404.

13 Széchenyire céloz. 
hol két évig tartott tanácskozások után sem lehet eltörleni a jobbágy szolgaságát s a földesúr önbíráskedását, biztosítani a parasztok személyét?" „... De gondolják meg - mondja tovább - a politikai régiségek szeretöi, hogy minden nemzetben a nagy többség áll velök szemközt, melynek türelmével visszaélni messzebb vezetne, mint ameddig a reformpártiak, századunk szelíd intéseinek engedve, jutni akarnak. És így talán tanácsosabb volna nekik, míg idő van egy eszélyes kapitulációról gondoskodniok, mintsem az ostromnak, melyet sokáig ki nem tarthatnak, ellentállva mindent kockáztatniok.

Hallám többízben - folytatta BALOGH - a jelen országgyúlés alatt említeni, hogy ha keblünkben nem fejlett volna ki oly nagyon a demokraciai elv, a kormány és a förendi tábla is hajlandóbb lett volna az általunk ajánlott morális engedélyek elfogadására; de miután mi a demokraciai elveket igen világosan kimondtuk, ők ezen engedményeket nyole százados alkotmányunk megrázkódtatása nélkül el nem fogadhatták. Tehát oly gyönge lábon áll már a magyar aristokrácia, hogy azt három úrbéri törvény megrendítheti? Vagy a jobbágy örökös szolgasága, a földesúr bíráskodása s a pálca önkénye azok az alapok, melyeken a magyar alkotmány nyugszik? Ha ez állana, úgy a magyar alkotmányt nem aristokraciának, hanem aristokratikus despotismusnak, oligarchiai zsarnokságnak vagy oly valami szörnyetegnek kellene tartani, melynek fogalmát kifejezni nem létezik szó az alkotmányosság szótárában. Bizonyára ezen észrevétel puszta merő ürügy s oly vékony szövésü lepel, melyen keresztüllátni nem nagy mesterség. Nem is lehet többé a nemzetek és a nagy közönség szemét kék gőzzel elkápráztatni.

Valódi oka annak, miért vonakodik a kormány, a felső tábla s az egyházi rend a morális engedményeket elfogadni nem más, mint hogy a kormány a nemzeti erő növekedése által a maga széles hatalmának megszorításától fél; a főrendek attól rettegnek, hogy az általok bálványozott aristokraciai elveket századunk elvei veszélyeztetik s ezek az ő oligarchiai kevélységöket s nagyravágyásukat korlátozandják; az egyházi rend meg azon kőszál beszakadásától remeg, melyre Péter az egyházat építette. És így ezen hármas szövetség kicsinyben ugyanazon célra törekszik, melyet magának az európai szövetség nagyban tüzött ki.

Nekem pedig mint az ellenzék tagjának, melynek koporsóm zártáig tartó hívséget ígérek, célom az, hogy e jelen veszteség által el nem rettentetvén, a szenvedő emberiségért addig fáradozzam, míg az említett elvek harcában legalább azon remény hajnala nem virrad, hogy a mi táborunkban is fog valahára lobogni a győzelem zászlaja, melynek látására a most szenvedő milliomok szemei a rájok nézve régtől fogva száraz magyar földet örömkönnyekkel fogják áztatni.“

A földesurak kínzó pálcájára vonatkozó szavait a személynök nem hagyhatta meg.jegyzés nélkül. - Hogy ez létezett volna - mondotta - eléggé megcáfolják a fennálló törvények, amelyek a visszaélésekre büntetéseket szabtak és így azokat gátolták. Amit pedig 
Balogh a reformerekről, democraticum principiumokról, kapitulációról előhozott, hazánk békés polgáraira nem alkalmazhatók. ${ }^{14}$

A magyar rendi világnak legellenszenvesebb intézménye kétségkívül az úriszék volt, amelyen a földesúr ítélkezett nemesak a jobbágvok közötti polgári perekben, hanem az úrbéri vétségekben is, tehát az utóbbiaknál a földesúr a saját ügyében volt bíró. Ezt a súlyos visszásságot kevéssé ellensúlyozta az, hogy a földesúr mellett két törvénytudó ülnök szerepelt, és jelen kellett azon lenni a járási szolgabírónak is (ez az eljárás szabályszerüségét volt hivatva ellenőrizni) esküdtjével. Ezek rendszerint a földesúrnak fogták pártját, épp így az elsố fellebbviteli fórumként müködő vármegyei törvényszék is. A bizottmányi munkálat a földesúrnak saját ügyében való bíráskodását azzal a sajátságos okoskodással igyekszik menteni: igaz, a földesúr a saját ügyében bíráskodik, de atyai jóakarattal van a jobbágy iránt, ezt pedig idegen bírónál nem lehet feltételezni. Most a két tábla között több üzenetváltás után létrejött javaslat mégis úgy rendelkezett, hogy jövőben az úriszékek esak a jobbágyok egymás közötti polgári pereiben fognak ítélni, a földesúr és a jobbágyok közötti úrbéri perek ellenben a megyei törvényszékekhez tartoznak.

Balogh az úriszéknek legnagyobb ellenzője volt. Az 1833. október 14-i ülésben azokról így nyilatkozott: „Az úriszék a Faustrechtnél is alábbvaló. Igen jól mondotta a soproni követ, ${ }^{15}$ hogy az úriszékek a gazságnak valóságos fabrikái. Olesóbban igazságtalanságot sehol se vehetni, mint az úriszékeknél." ${ }^{16}$ „Ha a többség az úriszékek megtartására hajolna a Mátyás király alatt volt példabeszéd arra változna által: él még az úriszék, oda az igazság" - mondotta a november 9-i ülésben. ${ }^{17}$ A főrendek az úriszék ,régi, tiszteletreméltó eredetét“ emlegették. - „Igenis - felelte BALOGH - az úriszékek eredete ama büszke várak sáncai közt keresendő, melynek omladékai szinte szánakozással néznek le hajdan hatalmas urak gyöngébb unokáira; ezek a bástyák immár összeomlottak s velök együtt örökre elenyészett az oligarchia büszke hatalma is; hagyjuk tehát nyugodni a már ártatlan mumiát, mert ha galvanismus segélyével némely tagját mozgásba hozhatnók is, azért halott maradnà mégis; temessük el inkább s bízzuk szépen regélő költőkre érdemtelen siratását". Az úriszékek teljes eltörlése felelt volna meg az ő hasonló kérdésekben vallott felfogásának, de második utasítása nem így szólt és így felfogásának nem tudott érvényt szerezni.

„Szívesen pártolta volna utasítása értelmében - mondotta az 1833. október 8-i ülésben - az úriszékek teljes eltörlését, pótló utasítása folytán azonban azoknak további megtartására kénytelen szavazni, de a következő megszorítások mellett. A már felszabadult jobbágyok, akik magokat és tartozásaikat megváltották, többé az úriszékek hatósága alá ne tartozzanak. Oly kérdések és perek, melyek-

\footnotetext{
14 Jegyzőkönyv X, 72-4.

15 Nagyl Pál.

16 $\rightarrow$ Jegyzőkönyv V, 241. 418.
} 
ben a földesúr fél és bíró is egyszersmind, az úriszék tárgyai többé ne legyenek. Harmadszor oly perek is vétessenek ki az úriszék hatósága alól, amelyekben az egyilk fél a bíráskodó földesúr hatalma alá nem tartozik. Azt nem látja át, amit az elölülő állított, hogy a úriszék szaporábban szolgáltatná ki az igazságot, mint más bíróságok, sót sokszor az ellenkezőt lehet látni. De egyébiránt is az igazság kiszolgáltatásában fő dolog maga az igazság, azután jön annak szapora kiszolgáltatása. Hogy pedig oly esetekben, hol a földesúr bíró és fél is, az igazság részrehajlatlanul nem szolgáltatik ki, azt a mindennapi tapasztalás inkább mutatja, mintsemhogy ezen állítást egyes esetek előszámlálásával támogatni kellene. $\mathrm{Ha}$ az úriszéket analysalni akarjuk, az az első kérdés, kikből áll az úriszék? A födesúrból, a szolgabíró és esküdtből úgy mint legale testimoniumból, ${ }^{18}$ a vármegye ügyvédjéből és az úgynevezett convocatusokból. ${ }^{19}$ A földesúr itt úgy áll, mint született bíró, már pedig lehet-e egy bíró szükséges tulajdonait magával e világra hozni? A legale testimonium, aki ha neki a földesúr voksot adni akar, az úrbéri tárgyakban bíró is, a földesúrtól diurnumokat kap, ez annyit tesz, mint a bírót az igazság kiszolgáltatásáért fizetni. A vármegye ügyvédje az úriszéken úgy áll, mint az adózó védője, némiképen qua tribunus plebis. ${ }^{20} \mathrm{De}$ ez is a földesúrtól diurnumot kap, ez annyit tesz, mint az ellenfél ügyvédjét fizetni. Ami a convocatusokat illeti, ezeket a jobbágy befolyása nélkül a földesúr magának választja. Tudja ő azt jól, kit kell neki meghívni az úriszékre és kit nem, hogy mindenesetre kedvező ítéletet nyerjen. Ily állapotban lévén az úriszékek, lehet-e oly kérdésekben, ahol a földesúr bíró is, fél is, igazságot várni a jobbágynak? erre feleljen a mindennapi tapasztalás. “21

Bár a szabadelvü ellenzék a tőle kívánt legfontosabb reformokat a förendek és a kormány ellenzése folytán minden erőfeszítése mellett sem tudta keresztülvinni, mégis a jobbágyok helyzetének javítása éretett el. A több rendbeli anyagi kedvezményeken kívül az úriszéket újra szabályozták. A földesúr bíráskodása megszünt, ezentúl úrbéri perekben egy megyei táblabiró elnöklete alatt két törvénytudó egyén bíráskodik (1836:X. t.-c. bevezetése). Megszünt továbbá a földesúr botoztatási joga, e helyett kihágás vagy úrbéri vétség esetében egy naptól három napig tartó fogság alkalmazható, a súlyosabb esetek az úriszékhez tartoznak (1836:X. t.-c. 3., 5. §-a). f́gy legalább a két legellenszenvesebb intêzmény, amelyeknek megszüntetéséért a szabadelvü követek a leghevesebben küzdöttek: a földesúr bíráskodása és botoztatása alól megszabadultak a jobbágyok. A modern államért küzdők fáradozásának e két nevezetes változás lett jutalma.

BALOGH főleg az úrbéri javaslat tárgyalásakor mutatta ki szabadelvü felfogását. Hangsúlyozta, hogy az ingatlanra vonatkozó tulaj-

18 Törvényszerű tanúskodás. Az úriszék eljárásának jogosságát ugyanis a szolgabíró és az esküdt ellenörizték.

19 Két törvénytudó ülnök.

20 A nép képviselője a bírói testületben.

21 Jegyzőkönyv V, 92. 
donjog a szabadság mellőzhetetlen része. Nem elég, hogy a jobbágynak több kenyere legyen, az ingatlanra vonatkozó tulajjonjog megadása által kell őt a szónak valódi értelmében emberré tenni. Ezt a reformot sürgetők sorában a legelsők között áll. Egyáltalában mindíg pártolta a jobbágyokat és jobb véleménnyel volt róluk, mint a legtöbben. - Ne gondoljuk azt - mondotta az 1833. október 29-i ülésben - hogy a jobbágy csak mindíg és mindenütt csalni akarná a földesurát.22

Különösen ki kell emelnünk a botbüntetés eltörlése mellett való síkraszállását. A nemes ember és a jobbáigy büntetése között fennállott nagy különbség felháborodást kellett, hogy keltsen az emberiesség és haladás híveiben. Az úrbéri javaslat tárgyalásakor az alsó tábla szabadelvü ellenzékének nem sikerült keresztülvinni, hogy a jobbágy személye a földesúrral szemben védve legyen. A személynök az erre vonatkozó VIII. törvénycikket feleslegesnek, sőt veszedelmesnek mondotta. A követek között is olyan hangok hallatszottak, hogy ha a javaslat törvénnyé válik, a jó rend, közcsendesség és bátorság fenekestől fel lesz forgatva. Akkor DeÁk fellépésére csak a X. törvénycikkben sikerült elvi kijelentést felvétetni.

A régi világ büntetôjogi felfogása is lényegesen különbözött a mai korétól. A kínzó vallatásokat a törvény a XVIII. század végén megtiltja ugyan, ${ }^{23}$ de nem a századok óta fennállott botbüntetést. A megyei tisztviselők kíméletlenül botoztatnak. A visszaélések megszüntetését célozza az 1820-i helytartótanácsi rendelet, amely szerint a megyei tisztviselők 12 bot- vagy korbácsütésnél többre nem büntethetnek, a kihágásról mindenkor jegyzőkönyvet kell felvenni, és az itélet végrehajtása tanúk jelenlétében történjék. De botoztatja a jobbágyot a földesúr és gazdatisztje is nemesak úrbéri vétségért, hanem bármiért, ami nem tetszik neki, így ha nem tér ki szekerével, ha vadászaton nem jól hajt, stb. „Sokszor hallani - írja Hasnóczy, a XVIII. század végének legkiválóbb publicistája - ebadta parasztja, 30-at veretek ré és a homágiumot, 40 forintokat leteszem“. Amint DeÁk kimutatta, nines törvény, amely a földesúrnak ilyen hatalmat adna, és az urbariális pálcát inkább elnézett visszaélésnek, bitorlott hatalomnak, mint törvényesített szokásnak lehetett tekinteni. De azért a botbüntetést, ha elvileg elvetik is, még szükségesnek mondják. Igy még Szécheny is, aki ellene van ugyan a botbüntetésnek miután az a jogegyenlőséggel ellenkezik, de Stádiumában a nép műveletlen állapotára való tekintettel némelyekre nézve azt még elkerülhetetlenül szükségesnek tartja és a nem nemest minden testi büntetéstől nem kívánja rögtön felmenteni, csak urai önkényétől kívánja a jobbágyot megvédeni, hogy „a mindent merészlő földesurak ne vámpyrkodhassanak büntetlen".

SzÉchenyi a Stádiumot 1831-ben irta, de miután a kormány a már nyomtatás alatt levő könyvet betiltotta, az csak 1833-ban jelent meg

22 Jegyzőkönyv V, 319.

23 1790:XLII. t. c. 
Lipcsében. A „legnagyobb magyar"-nak ebben a kérdésben elfoglalt álláspontja ellenkezik az ő humanizmusával, a társadalmi igazságosságra nézve vallott elveivel; ezt méltatói egyöntetúen nem tartják szükségesnek hangsúlyozni. Oo minden reform előfeltételének a nevelés útján elért érettséget jelölte meg. A botbüntetés eltörlése azonban más természetü kérdés volt, mint az egyéb reformok, mert az egyenesen az emberi méltósággal ellenkezett, eltörlését tehát nem lehetett a jobbágyság neveltebb állapotától feltételezni. Erre nézve még inkább áll az, amit BALOGH JÁNos 1834. november 10-i beszédében az örökváltságra nézve mondott: „Miféle érettség kell arra, hogy valaki örökös szolga ne legyen?" SzÉchenyı, a „józan és okszerü haladás" embere, aki magát „,becsületes progresszistának" nevezte, amikor a jobbágyot csak az önkénytől kívánja megvédeni, ugyanazon az állásponton van, mint NAGY PÁl az 1825-27-i országgyủlésen, panaszolván, hogy a II. József jobbágyrendeletében megengedett 12 pálcával „irgalom nélkül“ visszaélnek és a nép „minden érzés és kímélés nélkül veretik' ${ }^{24}$ Széchenyivel ellentétben DEÁK az értelmi fejlődés elérésére a köz- és magánszabadságnak nemesak párhuzamos, de elözetes létesülését is szükségesnek tartotta, mi nélkül az értelmi fejlödés nem érhető el. Szécheny álláspontjával teljesen megegyezö a fentemlített javaslat tárgyalása alkalmával az elnöknek ${ }^{25}$ az 1835. november 28-i ülésben tett nyilatkozata, amely szerint vannak ugyan olyan kimívelt vidékek, ahol testi büntetés nem igen szükséges, de tagadni nem lehet, hogy vannak olyanok is, ahol a testi büntetés mulhatatlan. Más követek is annak eltörlésében azt a veszedelmet látták, hogy a földesúr semmi hasznát nem fog.ja venni jobbágyainak. A kevesek között is, akik az eltörlés mellett vannak, olyan állásponttal találkozunk, aminő a nógrádi első követé, aki ugyan utasításának megfelelően az eltörlést kívánja, de ha már a testi büntetést fenn kell tartani, az ne botbüntetés, hanem vesszőzés legyen. Mintha bizony ezzel a dolgon elvileg valami változtatás történnék.

BALOGH nem az egyedüli, aki a botbüntetés eltörlését kívánta, ${ }^{26}$ de mindenesetre azok között volt, akik ezt az embertelenséget már nem tartották összegyeztethetőnek a korral. Buzgalmát erősítette DeÁknak e kérdésben elfoglalt álláspontja, aki kezdettől fogva az eltörlést kívánta, megtartását visszaélésnek mondotta, amelynek törvényes alapja ninesen. ${ }^{27}$ Gyökeres változást azonban ezúttal sem sikerült keresztülvinni, csupán enyhülést. A nemes ember és a jobbágy büntetése közötti különbséget is - miután a botbüntetést már a Deák

$24 \mathrm{Az}$ inhumánus gondolkozzás feletti méltatlankodásunk mellett ne feledjük, hogy közel száz év múlva az 1920. évi XXVI. te. egy évre ismét behozta a botbüntetést.

25 Somsick. Pongrác királyi személynök.

26 Ballagi tévesen mondja: „eltörlését az egyetlen Balogh János sürgeti s ő is esak föltételesen" [Vö. töle A nemzeti államalkotás kora 395].

27 Már legelső felszólalásában, az 1833. május 2-i kerületi ülésben kívánta, hogy a bírót vagy hegymestert a compossessorok sem bottal, sem másként ne büntethessék [Kónyi Manó, Deák Ferenc beszédei I, 9]. 
közremüködésével létrejött 1843. évi büntetőjogi javaslatok mellőzték ugyan, de ezen munkálatokból törvény nem lett - csak az 1848. évi törvényhozás szüntette meg a jogegyenlőség, tehát a büntetések egyenlőségének is, kimondásával.

Az alsó tábla javaslata szerint a megyéknek fenyítő hatalommal bíró tisztviselői, így a szolgabirák, három napi börtön vagy 12 botütésnél súlyosabb büntetést nem szabhatnak ki, e mellett a honoráciorok és a községi előljárók botbüntetéssel egyáltalában nem büntethetök. Ezt a javaslatot a főrendek nem fogadták el. Kimondatott azonban, hogy testi büntetéssel a bünös egy negyedév alatt ugyanazon ítéletnél fogva csak egyszer büntethető és ha az ítélet 25 botnál súlyosabb büntetésre szólna, az az elítéltre csak félévenkint alkalmazható (1836:XVII. t.-c. 2. §). Jellemzö a korra, hogy már ezt is olyan vívmánynak tekintették, amivel meg lehetnek elégedve.

Meg kell jegyeznünk, hogy BaLoGH beszédei nemesak értékes tartalmukkal tüntek ki, hanem egyike volt az alsó tábla legkiválóbb szónokainak. Ebbeli tehetségét Kossuth is elismerte.

A nép érdekében való lelkes küzdelme adott alkalmat a kormánynak arra, hogy három hütlenségi pere ${ }^{28}$ között az egyiket azért indíttassa meg ellene, mert az alsó tábla 1835. június 22-i ülésében magáévá tette WeSSELÉnYInek Szatmár megye 1834. december 9-én tartott közgyülésén a kormányról tett ama nyilatkozatát, amely szerint ez kilene millió ember, vagyis a jobbágyok zsírját szívja, s nem akarja, hogy a nemesség azokat segítse. A kormány ezt az állam ellen való izgatásnak minősítette és Wesselényi ellen hütlenségi pert indíttatott. BALOGH az alsó tábla fentidézett ülésében kijelentette, hogy Wesselényi beszédét nemesak nem kárhoztatja, hanem azt helybenhagyja és talán nem is vétene, ha azt magáévá tenné. ${ }^{29} \mathrm{E}$ kijelentése miatt ellene is hütlenségi pert indítottak, Bars megyére pedig ráirt a kormány, hogy miután a hütlenségi per alatt álló nem tarthatja meg követségét, új követet válasszon. A perindítás nagy izgalmat keltett. Az alsó tábla nem is akarta folytatni tanácskozásait, amíg a pert meg nem szüntetik. Ez a per adott kiválóan alkalmat az akkor már vezérszerepet vivő DeÁk Ferencnek arra, hogy az országgyülési szólásszabadság védelmében kifejtse azokat az alapelveket, amelyek a kérdés tárgyalásában késöbb is mindig irányadók voltak. Bars megye ismételten felírt a királyhoz Balogh perének megszüntetése érdekében, és a kormány paranesára nem hallgatva, július 25-i közgyülése őt megerősítette a követségben. Végül a kormány a közvélemény hatása alatt a pert október 9-én megszüntette. Ez a hütlenségi per nevezetes fejezete az országgyülési szólásszabadság történetének, mert ez volt az egyetlen eset, hogy az országgyülésben mondott beszéd miatt hütlenségi pert indítottak.

Követi működéséről Bars megye 1836. július 18-án tartott közgyülésén tett jelentést. A hazában - mondotta többek között - most

28 A hütlenség bélyege (nota infidelitatis) a régi büntetőjogban a legnagyobb büneselekmény, amelyre a törvények fej- és jószágvesztést rendeltek.

29 Jegyzökönyv X, 463. 
három politikai párt van. Az egyik minden embernek, a másik csak a nemesi kiváltsággal bíróknak, a harmadik esak a kormánynak és az oligarchiának kíván szolgálni. Ó különbség nélkül minden embernek, nemesnek, nem nemesnek, boldognak, boldogtalannak sorsán javítani, a nemesi kiváltságokat minden honfiúra kiterjeszteni, és mindazokat, akik századokon keresztül embereknek is alig tartattak, a magyar alkotmány kereteibe befoglalni kívánja. Az augusztus 29-i közgyülésben az alispán díszkardot adott át neki a megye elismerésének jeléül, majd 1842. június 7-én első alispánnak választották, amely tisztségét 1845 . október 20 -ig viselte. E minőségében sem szünt meg a haladás ügyét szolgálni.

$\mathrm{Az}$ 1848. július 5-én megnyilt országgyülésre az aranyosmaróti kerület képviselővé választotta. Ahhoz a kis számú ellenzéki esoporthoz tartozott, amelynek NyÁRy PÁL volt a vezére és GR. TELEKI László, Perczel Mór, Irányi Dániel, Madarász József és László voltak ismertebb tagjai. Törpe minoritás volt, ahogyan Kossuth elnevezte. BALogH később Kossuthnak egyik leglelkesebb híve lett, a szeptember 14-i ülésben kijelentette, hogy nincsen bizalma Batthyány miniszterelnökkel szemben, és a hazát csak úgy lehet megmenteni, ha a ház a kormányt Kossuth kezébe adja. Tagja volt annak a küldöttségnek, amelyet a képviselőház Deák vezetésével az osztrák biro dalmi gyüléshez menesztett, ezt az alkalmat felhasználva összeköttetésbe lépett a béesi demokratákkal, akik nagy rokonszenvvel fogadták. A szabadságharcban mint ezredes vett részt s kormánybiztosként müködött a Felvidéken. Mivel neve már régen a rebellisek névsorán szerepelt Bécsben, 1851. szeptember 21-én mint felségsértőt a pesti haditörvényszék in contumaciam halálra itélte és másnap az Ưjépület háta mögötti téren nevét 36 jeles hazafi - köztük Kossuth, Andrássy, Lónyay és mások - nevével együtt bitófára szegeztette. ${ }^{30}$ Törökországba menekülve ${ }^{31}$ Bemmel és másokkal együtt a sziriai Aleppóba internálták, majd Málta szigetén, Angliában és Németországban élt emigrációban nagy nélkülözések között, míg végre tíz évi bujdosás után engedély kérése nélkül próbált visszatérni. A határon azonban elfogták, és egy évig fogva tartották.

30 A vád ellene nemesak az volt, hogy résztvett a szabadságharcban, ezen felül az abszolút kormány azzal is vádolta, k.ogy ott lett volna a tömegben, amely a magyar kormány és az akkor már Magyarország ellen támadó Jellacsics horvát bán közötti közvetítésre Béesböl küldött gr. Lamberg Fereno pozsonyi föhadparanesnokot 1848. szeptember 28-án a Buda és Pest közötti hajóhídon meggyilkolta. Ezt a vádat Haynau lapja, a Pester Zeitung hangoztatta először Balogh ellen szeptember 29-i számában. A képviselöház ugyanaz napi ülésében ezt a vádat ő erélyesen visszautasította, rágalomnak mondotta és az egyáltalában ninesen bebizonyítva.

${ }^{31}$ Itt állítólag Bemmel és másokkal együtt ö is áttért a mokamedán vallásra, miután a török kormány ezt ajánlotta a menekülteknek, hogy biztosítva legyenek az osztrák és orosa kormány követelte kiadatással szemben. $\mathrm{Az}$ emigráció emlékíróinak tudósításai e tekintetben eltérők. 
Megyéje nem feledte el érdemeit és az 1861-i országgyülésre ismét képviselővé választotta. A megváltozott politikai légkörben és mivel egészségét is nagyon megviselték az emigráció szenvedései, ekkor már csendes emberré vált az, akinek eleme a népszabadságért, demokratikus haladásért való küzdelem volt.

Hátralévő éveit teljes visszavonultságban töltötte el szegényen, mert távolléte alatt esaládja vagyonából kiforgatta. Barátja, Wesselényi sorsában osztozott, már régebben meglevő szembaja annyira súlyosbodott, hogy majdnem egészen megvakult. „Én is részese valék anak a dicsőségnek - írja nem sokkal halála előtt egyik barátjának, - minőt a nemzet választottjainak osztogat. Azonban mi lőn mindennek vége? Életem rózsaágairól a virágok elfonnyadtak, esak tövisei maradtak... Nihil durabile sub sole!" 1872. január 11-én halt meg Érsekújváron 76 éves korában. „Temetésén - írja az egykori tudósitás - nagy tömeg jelent meg, egykori jobbágyai is. Elhatározták, hogy emlékének szobrot emelnek s erre meg is kezdték az adakozást."32

Mindenesetre BALOGH János azok közé tartozik, akik a leglelkesebben küzdöttek a népszabadságért, haladásért. Horváth Mrнály szerint a demokrácia és a republikánizmus iránti hajlamában a végletekig ment, s fiának már hét éves korában a következő katekizmust tanította be: $\mathrm{Ki}$ volt az első ember? Washington. Melyik a legjobb kormányrendszer? A köztársaság. Ki vagy te? Demokrata. Legjobb barátság füzte a kor legkiválóbb haladószellemü embereihez. Pozsonyban Deák társaságához tartozott, aki nem egy ízben támogatta országgyúlési felszólalásait és őt füssi birtokán többször felkereste. Nagyon jó viszonyban volt - amint ezt az Erdélyi Múzeum Wesselényi levéltárában őrzött levelei is mutatják - Wesselényivel és Köleseyvel. Demokrata, haladó magatartásáért az országgyúlési ifjúság nagyon kedvelte őt, többször fáklyásmenettel tisztelte meg és Wesselényit karonfogva ábrázoló képét kiadta. Bátor szókimondásáért nem egy támadás érte. Egyízben a nép érdekei mellett mondott szavai miatt egy királyi tanácsos az alkotmány ellenségének nevezte, mire ö kijelentette, hogy ő a nép érdekeit képviselve ül székén s e szerepben jobban tetszik magának, mint a követ úréban, aki esak Werbőczy kopott törvényeit jött autentikálni az országgyúlésre. A modern Magyarország megteremtésének, az 1848-ban diadalra jutott eszméknek egyik érdemes úttörője volt. Élete vége felé egyik barátjához intézett levelében nyugodt lelkiismerettel elmondhatta magáról, hogy minden leheletét már fiatal kora óta a közügyeknek szentelte, megtéve érettök mindent, mit tehetsége engedett. 
81. György Lajos: Anyanyelvünk védelme - 120.-

82. Grandpierre Edit: A kolozsvári Szent Mihály-templom tōrténete (34 képpel)

83. Balogh Ernõ: Dr. Szádeczky-Kardoss Gyula

84. Kozoesa Sándor: Históriás ének Bocskay Istvánról

85. Révész Imre: Méliusz ès Kálvin - -

86. Szabó T. Attila: Zilah helynévtörténèti adatai a XIV - XX. században - _ -

87. Lakatós István: $A z$ új magyar múzene

88. Rass Károly: A mi regényirodalmunk

89. Valentiny Antal: Románia magyar irodalmának bibliográliája, 1935. év $193 \overline{\text {. }}$

90. Monoki István: Romániábaa az 1935.
èvben megjelent román-magyar és magyar idószaki sajtótermékek cimjegyzéke

91. Szabó T. Attila: Nires-Szásznyires telepūlés, népiség- népesedés- és helynévIōrténeti viszonyai a XIII-XX. században

92 Janesó Elemér: Nyelv és társadalom -

93. Gyárfás Elemér: Gyárfás Elek útinaplója 1844-ból

94. Jászay Károly: Magyar luteránus megmozdulások Cluj-Kolozsváron (1798-1861)

95. Valentiny Antal: Románia magyar iro-

96. Kántor Lajos: Czegei gróf Wass ottilia, az Erdélyi Múzeum-Egyesūlet nagy jỏtevóje (4 képpel)

97. Szab6 T. Attila: A transylvan magyar

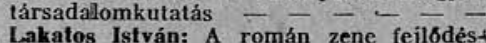
története (5 képpel)

99. Szabó T. Attila: Kelemen Lajos tudomảnyos munkásságának negyven éve (1897-1937)

100. György Lajos: Dr. Bitay Árpád életrajzi adatai és tudományos munkássága (1 képpel)

101. Szab́́ T. Attila: Dés helynevei (2 térképvázlattal)

102. Valentiny Antal: Románia magyar irodalmának bibliográfiája, 1937. év -

103. Makkai Endre-Nagy Ödön: Adatok 1éli néphagyományaink ismeretéhez - $\rightarrow-$

104. Szabó T. Attila: Bábony tōrténete és települése (68 képpel) - - - - -

105. György Lajos: Az ,Erdélyi Múzeum tôrténete (1874-1937) "- 1 - 300.-

106. Pábián Béla: Nagykend holynevei - 130.-

107. Herepei János-Szabó T. Attila: Levéltári adatok faépitészetūnk tōrténe téhez I. Fatemplomok és haranglábal

108. Szabó T. Attila: Levéltári adatok faépitészetūnk tōrténetéhez. II. Székelykapuk és fazárak - ----déki hirlapirodalom története a kiegyezésig

110. György Lajos: Dr. Rajka László élete is tudományos munkássága - -

111. Lakatos István: A muzsikus-Ruzitskák Erdélyben - - - - - $-\bar{n}-\overline{-}-\overline{-}$ clalmának bibliográfiája 1938 év

113. Domokos Pál Péter: Zemlény János kéziratos énekeskönyve (XVII. sz.) - -

114. Szabó T. Attila: A kalotaszegi nagybirtokok jobbágyságának szolgáltatása és adózása $(1640-1690) \quad \ldots \quad \ldots$

11.). Nagy Géza: Geleji Katona István személyisége levelei alapján - - -

116. Kántor Lajos: Párhuzam az Erdélyi Múzeum-Egyesũlet és az Astra megalakulásában és korai múkōdésében - -

117. Palotay Gertrud: Arva Bethlen Kata

118. Imre Lajos: A kōzmúvelódés mint tárBadogh feladat Artúr: A nemzetek Szōvetsége húsz évi múkōdésének mérlege -

120. György Lajos: A magyar nábob - -

121. K. Sebestyén József: A Cenk-hegyi Brasovia vár temploma (11 képpel) - -

122. Valentiny Antal: Románia magyar irodalmának bibliográfíja, 1939 .
1500.

250.

150.-

150.-

300.-

$120 .-$

200.-

400.150.-

250.-

300:-

(1)

600.-

$300 .-$

250.-

$\stackrel{?}{-1}-$

$-1$

$350 .-$

$-\frac{1}{2}$

$350 .-$

120.-

160.-

130.-

120.- -

150.-

150.-

3
123. Szabó T. Attila: Ujabb adatok és pótlá sok kéziratos énekeskönyveink és vorses kézirataink könyvészetéhez - -

124. Ady László: Magyarkapus helynevei (1 térképvázlattal) kének mocsárvilága (12 képpel és térképpel)

126. K. Sebestyén József: Régi székely népi eredetá múemiékeink (20 képpel)

127. Biró Veneel: Gr. Batthyány Ignác (1741 -1798) (1 képpel) - - - - -

128. Biró Sándor: A Tribuna és a magyar országi román kōzvélemény

129. Ferenezi István: Régészeti megfigyelések a limes dacicus északnyugati szakaszán (12 képpel)

130. Herepei János A dési református iskola XVII. és XVIII. századbeli igazgatói és tanítói

131. Palotay Gerirud: Régi erdélyi hímzésminta-rajzok

132. Tóth Zoltán: Iorga Miklós és a székeIyek román származásának tana - -

133. Jakó Zsigmond: Az Erdélyi Nemzeti Múzeum Levéltárának multja es feladatai

134. Entz Géza: A csicsókeresztúri római katolikus templom

135. Kristót György: Tudományos intézetek Erdélyben 1919-ig

136. Balogh ठdön: Néprajzi jegyzetek a csûgési magyarokról - - - - -

137. Debreczení László: Széljegyzetek egy népmũvészetūnkrôl szóló munkához -

138. Imre Barna: Mezóbånd helynevei - -

139. Mikó Imre: A tōrvényhozói ōsszeférhe

140. Biró Vencel: Gróf Zichy Domonkos Erdélyben

141. Entz Géza: A dési református templom (20 képpel)

142. Tolnai Gábor: Gróf Lázár János, a VolIaire-forditó

143. Herepei János: Kōnyvészeti tanulmányok

144. Naǵy Géza: Társadalmi ellentétek a régi erdélyi református egyházban -

145. Tóth Zoltán: A román tōrténettudomány és a székelyföldi románság kérdése -

146. Kelemen Lajos: Radnótfája tôrténete -

147. Szabó T. Attila: Dés tellepūlése és lakassága Sándor: A két Apafi fejedelem

148. Tavaszy Sándor: A két Apafi fejedelem
149. Németh Gyula: Kóroósi Csoma Sándor lelki alkata és fejlódése (1 képpel) -

150. Entz Géza: Szolnok-Doboka középkori múemlékei (9 képpel) - - - -

151. Makkai László: Szolnok-Doboka megye magyarsága

152. Györffy István: Erdély virágtalanjai -

153. Balogh Artúr: Erdély nemzetiségi kêrdései dalmának bibliográfiája 1940-ben és 1941-ben $\rightarrow--\ldots$

155. György Lajos: A Benigni-könyvtár -

156. Gazda Ferenc: Gr. Kemény József és Mike Sándor levelezése _ _ _ -

157. Makkai Lásłłó: Az erdélyi románok a kōzépkori magyar oklevelekben -

158. Vita Zsigmond: A Bethlen kollégiumi színjátszás a XVII. és XVIII. században

159. Palotay Gerirud-Szabó T. Attila: Mezóségi magyar himzések (137 képpel) -

160. Miḱ Imre: A magyar államnyelv kérdése a magyar országgyúlés elótt - -

161. Borbély Andor: Erdélyi városok képeskōnyve (22 képpel) _ $\quad \ldots-$

162. Entz Géza: A kōzépkori székely múvészet kérdései (16 képpel) - - -

163. Cs. Bogáts Dénes: Háromszéki oklevélszójegyzék

164. Kristóf György: Fadrusz Mátyás királya és Vörōsmarty Szép Ilonkája - - -

165. Ferenexi István: Csikkarcfalvi régiségek

166. Herepei János: Scholabeli állapotok Apáczai Kolozsvárra jôvetele elơtt (4 kóppel)

150. 250. 300.180.

100.-

400 .

250. -

200.-

200.

300.

350.

200.-

300.

100.

150.-

100.

250.-

250.

400.

300.

200.-

150.

100.-

$250 .-$

350

150.

1500 .250. 800. 600. 1200.

150. 
167. Lássib́ Grola: Erdely telepảléstôrtínetének vázlata Szeni Istuán koráig (1 színes térképvázlattai) _ _ _ _ -

168. Nagy Jenó: Lakodalom a kalotaszegi Magyarvalkón - $-\overline{-}-\overline{-}$

169. Mozsolies Amália: A magyarorszáą bronzkor kronológiajáról - $-\overline{-}-\overline{-} \overline{\text { Z }}$ kollégium ifjúságának irodalmi tôrekvései a reform-korszak kezdetén - 1646-47. évi összeírása (6 térképvázIattal) - - - ótélyi római - - likus púspōki szék betōltésének vitája a XVi1. században - - - -

173. Kristóf Györdy: Reményik Sándor - -

174. Makluai Ern6: Sipos Pál és Kazinczy Ferene - Kóncori temetoink feltárásmódjáról (8 képpel) - - -

176. Nagy Jenó: Család-, gúny- és ragadványnevek a kalotaszegi Magyarvalkón

177. Zsaḱ́ Gyula: Egy XVIII. századi torockói naplo (2 képpel) - - $-\ldots$

178. Vita Zsigmond: Románia magyar iro-

179. Palotay Gertrud: A szolnokdobokai Szék magyar himzései (68 képpel) - (1 têrképvázlattal) - - - L - -

181. Sxabó T. Attila-Gálfiy Mózes-Máton Gyula: Huszonót lap ,Kolozsvár és vi dêke népoyelvi têrképê"-bô) (26 térkêplappa:
Lej

$450-$

200.-

100.-

250.-

1200.-

$250 .-$

200.-

$300 .-2$

400.-

200.-

250.-

200.-

1200.-

250.-

$500 .-$
182. 1. Nazz Otíb: Gyarmathi Sámuel élete Ė munkássága (2 képpel) - co haladás az erdélyi jog fejlốdésében _- -

181. Venezel József: A volt határórezredck vagyonának sorsa - _ _ - _ -

185. Balog̣h Artúr: Hũtlenségi per országgyúlési beszéd miatt - - - -

186. Balogh Jolán: Pákei Lajos rajzai Ko lozsvár épitészeti emlékeiról (31 képpel) 1000.-

187. Guoth Kâlmán: Eszmény és valóság $\mathrm{Ar}$ pádkori királylegendáinkban _ -

188. Kováes Agnes: A kalotaszegi Ketesd mesekincse

189. Tárkány-Szũes Ernó: A juhtartás népi jogszabályai Bảlványosváralján —

190. Mikees László: Uj erdélyi tudomány - 350.-

191. Busa Lászlo: A Szocialista Szovjet Kōztársaságok Uniója mint ósszetett śllam 240.-

192. Bir6 Veneel: A kolozsvảri jezsuita egyetem szervezete és épitkezései a XVIII. században $\overline{-}-\overline{-}-\overline{-}$

193. † Gergely Bela- Srab6 $T$. Attila: A szolnokdobokai T6ki vōlgy helynevei - - ềúsek kutatása - - - - - - -

195. Faragó J6zsel: A "Remény" harmadik kötetének kérirata - - - -

196. Ĺsszl6 Gyula: A korszerú régèszeti múzeum. (Tanulságok a kievi Tôrténeti Múzeum kiállításáról (2 képpel) - -

197. Márten Gjula: A szolnokdobokai Arpástó helynevei -

198. Balozh Artár: A jobbagyfelszabaditís egyil Ielkes harcosa a reformkorban 500.-

\section{Ax árjelués mélkâli extimok elfogytak.}

\section{AZ BRDALYI MOZEUM-EGYBSULET JOG-, KÖZGAZDASAG- US TARSADALOMTUDOMANYY SZAKOSZTALYÁNAK GRTEKEZESSW}

1. Gsekei István: Tehete a kózigazgatásí intézkedéżel kivételt a miniszter saját rendelete alóli 100.-

2. Buza Lásấo: A lórjog és a magánjog fogalmi clhatárolásának kérdése. - Vitéz Moór Gyula:

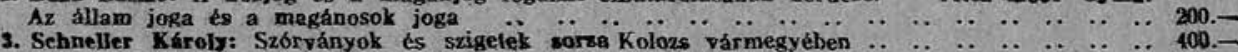

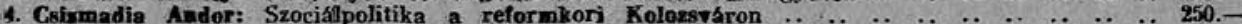

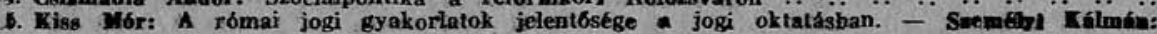

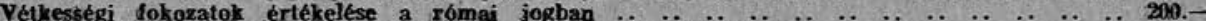

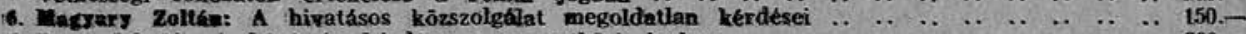

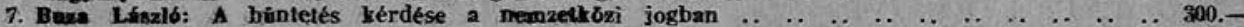

\section{AZ ERDGLYI NEMGETI MCZBUA HEVATTARANAK KIADVÁNYAI}

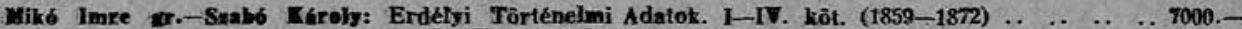

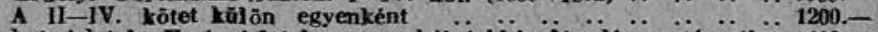
Jaḱ Zsirmond: Erdélyi Tórténelmi Adatok. V. 1. Adatok a torockbi jobbágylázadás történetéhez $600 .-$ Jakb Zsizmond: Az Erdélyi Nemzeti Múxeum Levéltárának múltja és feladatai .. .. .. .. 200.Jalḱ Zsigmend: Jelentés az Erdélyi Nemzeti Múzeum Levéltárának 1942. évi múködésérọ́ .. .. 150.Jak6 Zsigmend: Jelentés az Erdélyi Nemzeti Múrzenm Levéltárának 1943. évi múkōdésérốl ... 200.Jaḱ Zsigmond-Valentiay Antal: A torockószentgyôrgyi Thorotzkay-esalád levéltára (Két oklevèj-

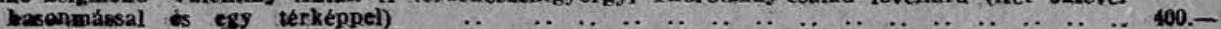

\section{Megrendelhetôk an Firdelyi Múzemm kiadóhivatalaban} Kolozevar, Kirally-aten 14. 


\section{Erdélyi Tudományos Füzetek EME}

\section{Megindította György Lajos}

1. Rass Károly: Reményik Sándor

2. Pârvan Bazil: A dákok Trójában -

3. Bitay Árpád: Gyulafehérvár Erdély múvelóléstörténetétben - - - -

4.Bitay Árpád: A moldvai magyarság -

5. Szokolay Béla: A nagybányai múvészcelep

6. Balogh Ernō: Kvare az Erdélyi medence fels $\delta$ mediterrán gipszeiben - -

7. György Lajos: Az erdélyi magyar irodalom bibliográfiája, 1925 . év - brassói fekete templom Mátáys-kori címerei - - -

9. Karáesonyi János: Uj adatok és új szempontok a székelyek régi történetéhez

10. Gál Kelemen: Brassai küzdelmei a magyartalanságok ellen

11. Tavaszy Sándor: Erdélyi szellemi éle-

12. Györ két dōntổ kérdése Két dialógus régi magyar irodalmunkban (1 hasonmással)
K. Sebestyén József: A A Becse-Gergely nemzetség

14. Ferenezi Miklós: Az erdélyi magyar irodalom bibliografiája. 1926. év - -

15. Gyárfás Elemér: A Supplex Libellus Valachorum

16. Rónay Elemér: Kemény János fejede-

17. György Lajos: Egy állitólagos Panesaitantra-származék irodalmunkban dalom bibliográfiája, 1927. év - - -

19. K. Sebestyén József: A kōzépkori nyugati múveltség legkeletibb határai -

20. Szabó T. Attila: Az Erdélyi MúzeumEgylet XVI-XIX. századi kéziratos énekeskōnyvei

21. Ferenezi Miklós: $\overline{A z}$ erdélyi magyar irodalom bibliográfiája 1928 . év pótlásokkal az 1910-1928. évról _ -

22 György Lajos: A francia hellénizmus hullámai az erdélyi magyar szellemi eletben

23. Kántor Lajos: Az Erdélyi MúzeumEgyesũlet problémái _ _ - - -

24. Gál Kelemen: A nemzeti nevelés román fogalmazásban

25. Tavaszy Sándor: Kierkegaard személyi-

25. Papp Eerene: Gyulai Pál id. Bethlen János gr. kōrében - $-\overline{-}-\overline{\text { jegyzetek a }}$

7. Csũry Bálint: Néprajzi jegyzetek a Biró Vencel: Púspōkjelólés az erdélyi róm. kath. egyházmegyében - -

9. Teleki Domokos gróf: A marosvásár-

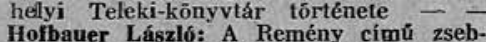
kōnyv tōrténete $(1839-1841)$

31. Ferenczi Miklós: Az erdélyi magyar irodalom bibliográfiája, 1929. év -

32. Gyalui Farkas: A Dōbrentei-pályázat és a Bánk bán $\overline{\text { Rajka László }} \overline{\text { Tōorōkvilág }}-\frac{\mathrm{Ma}}{-}$

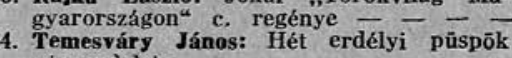
végrendelete

35. Bir6 Vencel: A kolozsmonostori bels jezsuita rendház és iskola Bethlen és a Rákóczy fejedelmek idejében -

36. Szabó T. Attila: Az Erdélyi Múzeum Vadadi Hegedüs-kódexe _ $\ldots$

37. Kántor Lajos: Hidvégi gróf Mikó Imre szózata 1856-ban az Erdélyi Múzeum és az Erdélyi Múzeum Egyesũlet megalaki-

tása érdekében $\mathrm{Az}$ erdélyi magyar irodalom bibliográfiája. 1930 . év -
Lej

Lei

39. Balogh Artúr: A székely vallási és György Lajos: Eulenspiegel magyar nyomai - -----

41. Dömötör Sándor: A cigányok temploma

42. Kristóf György: Báró Eōtvōs József utazásai Erdélyben $\overline{\text { Hofbauer László: }}$ Erdélyi Hiradó Hoíbauer
tōrténete

44. Kristóf György: Kazinczy és Erdély -

45. Asztalos Miklós: A székelyek óstōrténete tetelepuñesūkig

46. Varıa Béla: $\mathrm{Az}$ individualitás kérdése

47. Kemény Katalin: Erdélyi emlékirók -

48. Dömötör Sándor: Vida György facetiái

49. Oberding József Györqy: A mezőgazdasági hitelkérdés rendezésére irányuló törekvések a román tōrvényhozásban

50. Szabó T. Attila: Kōzép-Szamos-vidéki határnevek

51. Balogh Jolán: Olasz falfestmények Gyulafehérvárt $\quad \ldots+\ldots$

52. Ferenezi Miklós: $\overline{A z}$ erdélyi magyar irodalom bibliográfiája, 1931. év - -

53. Kántor Lajos: Magyarok a román népköltészetben

54. György Lajos: Magyar anekdótáink Naszreddin-kapcsolatai Kemény József (1795-1855) (12 képpel) - - - -

6. Kántor Lajos: Kölesönhatás a magyar és román népkōltészetben _- -

150.

250.-

57. Tavaszy Sándor: A lét és valóság -

58. Szabó T. Attila: Adatok Nagyenyed
XVk-XX. századi helyneveinek ismeretéhez (1 térképvázlattal) - -

59. Imre Lajos: A falunevelés irányelvei

60. Veress Endre: A tōrténetíró Báthory István király (3 képpel) _ - -

61. Bores György: Carlvle pūspōkapát a XVI. században

63. Bíró József: A kolozsvári Bánfify-palota és tervezo mestéré, Johann Eberhard Blaumann ( 7 képpel) - $-\ldots$

64. Ferenezi Miklós: Az erdélyi magyar irodalom bibliográfiája. 1932. év - -

65. Janesó Elemér: $A z$ irodalomtōrténetírás legújabb irányai tūkrōzó román irodalomban _- -

67. Veress Endre: A moldvai csángók származása és neve

68. Oberding József György: A Kolozsvári Gondoskodó Társaság _ - - -

200.-

69. Papp Ferene: Gyulai Pál a kolozsvári ref. kollégiumban - - - --

70. Ferenezi Mikł6s-Valentiny Antal: Az erdélyi magyar irodallom bibliográfiája. 1933. év

71. Balogh Jolán: Márton és Gyōrgy kolozsvári szobrászok' - - - - 250.- 72. Kristóf Györty: Szaboleska Mihály

73. Lakatos István: Magyaros elemek

74. Kristóf György: Eminescu Mihály kö̊teményei Jórof: A boñchidai Bánffy-kastély

76. Juhász Kálmán: Múveltségi állapotok $\bar{a}$ Teméskôzben a törōk világban - -

77. Rajka László: Jókai román tárgyú novellai.

78. Venezel József: A falumunka és az erfalumunka-mozgalom ㄴ - $-\ldots$

79. Valentiny Antal: Az erdélyi magyar iro150.- $\quad$ dalom bibliográfíaja, 1934. év mưvészet

.--
.--
$-\cdot-$
$250 .-$
.--
.--
.--
--
.--
.--

(5).

250:-

400.-

200.

200. -

250.-

-

-.-

$600 .-$

250.-

100.-

-..

-..

-.

300.-

-..

- . -

.-
-.4

120.-

150 .

250.- 